\title{
IS THERE ANYTHING LIKE A UNIVERSAL TYPOLOGY OF TRANSLATION SOLUTIONS FOR CULTURE-SPECIFIC ITEMS?
}

\author{
Magdaléna Bilá, Alena Kačmárová, Prešov University, Slovakia, \\ alena.kacmarova@unipo.sk
}

10.31902/fll.24.2018.5

UDK 82.035

\begin{abstract}
Rendering culture-specific items (CSI) into another language has always been a challenge for translators for obvious reasons: CSIs are context-dependent text elements carrying a connotative meaning in the source culture. For the same reason, several typologies are available, like Newmark's (1988), Tomaszkiewicz's (1993), Valdeon's (2008), or Pedersen's (2011). Newmark's typology has been generally accepted by experts in translation studies and translation pedagogy. Tomaszkiewicz's (1993) eight strategies are based on exploring subtitling in films; Valdeon's taxonomy (2008) based on audiovisual mode comprises strategies resulting from preservation and from substitution. Pedersen's taxonomy (2011) involves source-language-oriented and target-language-oriented ones. These can be juxtaposed with Pym's (2016) taxonomy, which he calls a typology of translation solutions for many languages. He (ibid) assumes them to be behavioral, problem-based, potentially conscious, intersubjective and starting from the most general and basic translation solution: to change something. With the arrival of something new, a couple of questions may arise: Why do we need still another classification? How is this approach different? Our basic premise is that Pym's typology is more user-friendly (i.e. translator-friendly). The present paper aims to compare and contrast the existing typologies and in doing so streamline the current trend in the translation theory.
\end{abstract}

Key words: culture-specific item, translation strategies, translation solutions, film dialog, Pym (2016), Pedersen (2011), Valdeon (2008), Tomaszkiewicz (1993), Newmark (1988)

\section{Introduction}

It is axiomatic that a translator's intention is to communicate the message without first reaching for a theoretical explanation. However, the tradition of translating bears witness to numerous typologies of translation strategies. The latest contribution is the taxonomy of translation solutions proposed by Pym (2016). One may ask why we still need another classification, whether or how Pym's approach is different from those before him. Further questions that 
arise are what purpose all the typologies serve, what role they play in actual translating, whether they operate as practical mechanisms or whether they are mere theoretical constructs. The present study aims to contribute a critical overview of typologies of culture-specific items (hereinafter abbreviated as CSI) and translation strategies so that we can tentatively state whether or not the existing typologies are functional, in the sense of bringing actual benefit in the process of translating (here, namely CSIs). We are interested in to what extent some of the strategies are or are not constructive in contributing the true message when translating from one language into another.

The present study represents a critical overview of the terminology of translation strategies that can be applied in translating culture-specific items. Firstly, culture-specific items are defined to illustrate the complex nature of the translation strategies to be used (Section 1); we refer to Nida's (1975), Vlachov and Florin's (1980), Newmark's (1988), and Nord's (1997) taxonomies of CSIs. Secondly, the evaluation of the typologies of translation strategies, by means of conceptualization process, is presented (Section 2). Within the latter, we devote space to Newmark's (1988) terminology and how it works in practice; we compare Newmark's typology with those by Tomaszkiewicz (1993), Valdeon (2008), and Pedersen (2011); we give an overview of Pym's approach (2016); and lastly, we interrelate Pym's approach (2016) and those by Newmark (1988), Tomaszkiewicz (1993), Valdeon (2008), and Pedersen (2011).

\section{Culture-specific Items}

In recent years, a culture-specific item has been receiving much attention from various fields of study. It has been approached by experts in lexical semantics, phraseology, translation studies, language acquisition, and the like. For this reason, several taxonomies have appeared and the mere concept has received several tags. It follows that more definitions are in use, which makes it complicated to find a universal one. A useful approach might be interpreting a CSI as a linguistic sign with its three components: signifier, signified, and referent. Our understanding is that a signifier represents a form, i.e. a label; signified represents the content; and the referent represents the mere exemplification.

Signifier is represented by terms used for naming a culturespecific item, which varies with authors in the following way. Nida (1975) calls them cultural features; Newmark (1988) tags them either foreign words or cultural words; Vlachov, Florin (1980) use the term 
realia; Nord (1997) calls them alternatively culture markers or culturemas; the latest approach is found in Sipko (2010) who names them linguoculturemas.

Signified represents the content named by the above terms, which again varies with authors. Nida (1975), Vlachov and Florin (1980), Newmark (1988), and Nord (1997) consider different criteria for classification of what their idea of the term/signifier of CSI comprises; hence, their signified is represented by the bulleted items in Table 1.

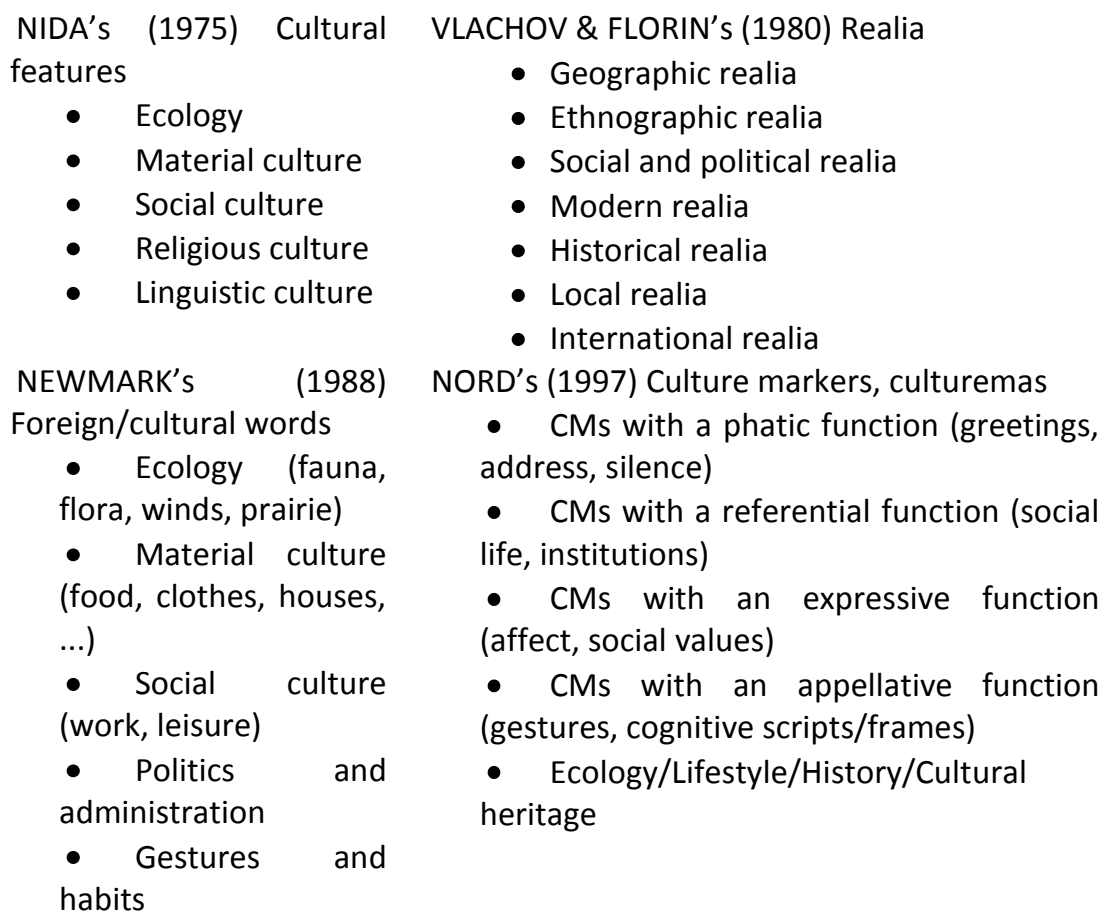

Table 1 Taxonomy of CSI inventory

The referent is the mere exemplification in a specific context. The following examples can serve the illustration; they originate in the dramedy series Gilmore girls 2000 - 2007.

(1) Rory: Ugh, that's so Nick at Night.

(2) Lorelai: You look like you were swallowed by a kilt.

(3) Rory: I mean, I know it's kind of cliché to pick Moby Dick as your first Melville but...

(4) Rory: Okay. I love being a private school girl.

(5) Rory: Jessy called an ambulance. 
In our discussion above, CSIs are treated as linguistic signs. The interrelationship between the three components can be explicated as follows. In example 1, Nick at Night names a show most probably unknown outside the USA, thus specific of this culture. For this reason, it represents social culture (Nida 1975, Vlachov and Florin 1980, Newmark 1988); and it is a CM with a referential function (Nord 1997). In example 2, kilt represents material culture (Nida 1975, Newmark 1988), ethnographic realia (Vlachov and Florin 1980), or a CM with a referential function (Nord 1997). In example 3, Moby Dick implies social culture (Nida 1975, Vlachov and Florin 1980, Newmark 1988) and it is a CM with a referential function (Nord 1997). In example 4, in private school girl in the context provided by the episode concerned, the reference is being made to a uniform, hence material culture (Nida 1975, Newmark 1988) or ethnographic realia (Vlachov and Florin 1980); when applying Nord's typology (1997), we can see an overlap between a CM with a referential function and lifestyle culturema. In example 5, ambulance embodies linguistic culture (Nida 1975) or a CM with an appellative function (a cognitive frame) (Nord 1997). Table 2 offers the summary of the differences in the classification of the studied CSIs. The complex nature of these linguistic signs only presupposes their being bump situations in the process of translating.

\begin{tabular}{|c|c|c|c|c|}
\hline & $\begin{array}{l}\text { Nida } \\
\text { (1975) }\end{array}$ & $\begin{array}{l}\text { Vlachov, Florin } \\
\text { (1980) }\end{array}$ & $\begin{array}{l}\text { Newmark } \\
\text { (1988) }\end{array}$ & $\begin{array}{l}\text { Nord } \\
(1997)\end{array}$ \\
\hline $\begin{array}{l}\text { Nick at Night } \\
\text { Kilt } \\
\text { First Melville } \\
\text { Private } \\
\text { school girl }\end{array}$ & $\begin{array}{l}\text { social c. } \\
\text { material c. } \\
\text { social c. } \\
\text { material c. }\end{array}$ & $\begin{array}{l}\text { social c. } \\
\text { material c. } \\
\text { social c. } \\
\text { material c. }\end{array}$ & $\begin{array}{l}\text { social c. } \\
\text { ethnogr. r. } \\
\text { social c. } \\
\text { ethnogr. r. }\end{array}$ & $\begin{array}{l}\mathrm{CM} \text { with ref. function } \\
\mathrm{CM} \text { with ref. function } \\
\mathrm{CM} \text { with ref. function } \\
\mathrm{CM} \text { with ref. function, } \\
\text { lifestyle culturema }\end{array}$ \\
\hline Ambulance & linguist. c. & -- & -- & CM with appellative $f$. \\
\hline
\end{tabular}

\section{Translation strategies}

\subsection{Newmark (1988)}

In the translation studies, the typology of translation strategies most often referred to is that by Newmark (1988), since it has become generally accepted and adopted terminology. Here, we refer to our micro corpus of five CSIs and provide its translation into Slovak in order to exemplify the application of Newmark's (1988) strategies. The dubbed version of the audiovisual text concerned offers the translation outcomes given below. Each example contains five pieces of 
information: 1) the original English statement from the studied dramedy series, 2) the authentic Slovak statement, 3) its literal translation into English (so that the language structuring can be obvious), 4) our assessment of the translation strategy the translator chose, and 5) a commentary on the translator's decision in terms of retaining or avoiding content, form, or both.

\section{Example 1}

1. Rory: Ugh, that's so Nick at Night.

2. Rory: Ach to je také banálne.

3. Oh, this is so banal.

4. generalization

5. The original expression and the translated expression do not share form; however, the content is shared, though at first sight it might not seem so. The translator managed to express the content - a Slovak viewer would not know of the show, so the translator rightly opted for an expression that the idea of which would correspond with the message of the show.

\section{Example 2}

1. Lorelai: You look like you were swallowed by a kilt.

2. Lorelai: Vyzeráš ako Škót v sukni.

3. You look like a Scotsman in a skirt.

4. omission + explication (with a shift)

5. The original expression and the translated expression share neither content nor form. The content of the Slovak translation is simplified since the reference to an oversize kilt is missing. The form differs in that the English original is a passive structure with a by-agent and the Slovak version is a prepositional phrase.

\section{Example 3}

1. Rory: I mean, I know it's kind of cliché to pick Moby Dick as your first Melville but...

2. Rory: Viem, že je to otrepané povedat', že Moby Dick je moja oblúbená kniha...

3. I know, it's kind of a cliché to say that Moby Dick is my favorite book...

4. borrowing

5. the outcome shares both content and form (because it is imported) 


\section{Example 4}

1. Rory: Okay. I love being a private school girl.

2. Rory: Dobre. Teším sa do tej školy.

3. Fine. I'm excited about that school.

4. generalization

5. The original expression and the translated expression partially share both form - the semantic element 'private' is omitted, which is justifiable due to different conceptualization of the compound private school in English and súkromná škola in Slovak. Due to cultural differences, the content could not be retained and needed tailoring.

\section{Example 5}

1. Rory: Jessy called an ambulance.

2. Rory: Jessy zavolal *ambulanciu. [the proper Slovak equivalent is sanitka/záchranka/rýchla pomoc]

3. Jessy called a *doctor's office.

4. literal translation, *improper

5. The original expression and the translated expression share form, however, they provide completely different conceptualization, hence the Slovak expression is considered a translator's lapse.

The translation strategies we identified in the chosen examples demonstrate their varying functionality. They were identified based on the evaluation of how much of the form and content - two facets of a CSI as a language sign - was retained and with what effect. Table 3 summarizes the classification of the referents and translation strategies based on their content and form. The summary is only illustrative; it is not meant to represent research on CSIs, let alone large-scale. Rather, it serves as a platform for research into streamlining the terminology of translation strategies. Furthermore, it hints vertical and horizontal relationships between and/or among the present concepts. In the table, the tinted area represents the focus of our study; more precisely, a benchmark with which other typologies of translation strategies are compared and contrasted in the following section/s.

referent

Classification of CSIs

content+form Translation

Nida

Vlachov,

Newmark

Nord strategies

Newmark 


\begin{tabular}{|c|c|c|c|c|c|}
\hline $\begin{array}{l}\text { Nick at } \\
\text { Night }\end{array}$ & $\begin{array}{l}(1975) \\
\text { social c. }\end{array}$ & $\begin{array}{l}\text { Florin (1980) } \\
\text { social c. }\end{array}$ & $\begin{array}{l}(1988) \\
\text { social c. }\end{array}$ & $\begin{array}{l}\text { (1997) } \\
\text { CM with ref. } \\
\text { function }\end{array}$ & $\begin{array}{l}(1988) \\
\text { generalization }\end{array}$ \\
\hline Kilt & $\begin{array}{l}\text { material } \\
\text { c. }\end{array}$ & material c. & ethnogr. $r$. & $\begin{array}{l}\text { CM with ref. } \\
\text { function }\end{array}$ & $\begin{array}{l}\text { omission }+ \\
\text { explication } \\
\text { (with a shift) }\end{array}$ \\
\hline $\begin{array}{l}\text { First } \\
\text { Melville }\end{array}$ & social c. & social c. & social c. & $\begin{array}{l}\mathrm{CM} \text { with ref. } \\
\text { function }\end{array}$ & borrowing \\
\hline $\begin{array}{l}\text { Private } \\
\text { school girl }\end{array}$ & $\begin{array}{l}\text { material } \\
\text { c. }\end{array}$ & material c. & ethnogr. $r$. & $\begin{array}{l}\text { CM with ref. } \\
\text { function, } \\
\text { lifestyle } \\
\text { culturema }\end{array}$ & generalization \\
\hline Ambulance & $\begin{array}{l}\text { linguist. } \\
\text { c. }\end{array}$ & -- & -- & $\begin{array}{l}\text { CM with } \\
\text { appellative } \mathrm{f} \text {. }\end{array}$ & $\begin{array}{l}\text { literal } \\
\text { translation, } \\
\text { *improper }\end{array}$ \\
\hline
\end{tabular}

Table 3 Classification of the studied CSIs and utilized translation strategies

\subsection{Newmark (1988) versus Tomaszkiewicz (1993), Valdeon (2008), and Pedersen (2011)}

Since Newmark (1988), other typologies have appeared. Out of them, the typologies by Tomaszkiewicz (1993), Valdeon (2008), and Pedersen (2011) seem relevant to us, as the present study makes references to examples of CSIs in film dialog. Tomaszkiewicz (1993) proposed eight strategies based on exploring the subtitling in films. Valdeon (2008) suggested seven strategies falling into two groups preservation and substitution: preservation of CSI and that of an international item; substitution with a target-culture item, with corrupted forms of the target culture item (on the term corrupted, cf Valdeon 2008), with superordinate item, with an international item, and with a different source-culture item. Pedersen (2011) offered seven strategies falling in two groups: source-language-oriented and target-language-oriented.

Contentwise, Tomaskiewicz's (1993), Valdeon's (2008), and Pedersen's (2011) strategies are identical with Newmark's (1988) strategies of omission, borrowing, equivalence, literal translation, adaptation, generalization, substitution, and explication; though for some, the above authors use different labels. From our perspective, in the core meaning, they overlap with Newmark's in the way presented in Table 4. The tinted areas mean the absence of a generally accepted strategy in the author's typology; the white areas mean that the author uses an identical term; and the white area with a caption means that 
the author recognizes a generally accepted concept, yet uses a different term for it. In the below table, these different terms are matched with generally accepted terms based on our understanding of their core meaning. We indexed one strategy with an asterisk to suggest its double occurrence; i.e. its possible double conceptualization - either identical with equivalence or with substitution by virtue of the context requirements.

\begin{tabular}{|c|c|c|c|}
\hline $\begin{array}{l}\text { Generally accepted } \\
\text { terms }\end{array}$ & $\begin{array}{l}\text { Tomaszkiewicz } \\
\text { (1993) }\end{array}$ & Valdeon (2008) & $\begin{array}{l}\text { Pedersen } \\
\text { (2011) }\end{array}$ \\
\hline \multicolumn{4}{|l|}{ OMISSION/DELETION } \\
\hline BORROWING & & $\begin{array}{l}\text { Preservation of } \\
\text { CSIs; } \\
\text { Preservation of } \\
\text { an international } \\
\text { items }\end{array}$ & Retention \\
\hline EQUIVALENCE & & $\begin{array}{l}\text { *Substitution } \\
\text { with a target- } \\
\text { culture item }\end{array}$ & \\
\hline $\begin{array}{l}\text { LITERAL } \\
\text { TRANSLATION }\end{array}$ & & & $\begin{array}{l}\text { Direct } \\
\text { translation } \\
\text { a)calque, } \\
\text { b)shifted }\end{array}$ \\
\hline ADAPTATION & & $\begin{array}{l}\text { Substitution with } \\
\text { corrupted forms } \\
\text { of TC item }\end{array}$ & \\
\hline GENERALIZATION & $\begin{array}{l}\text { Naturalization } \\
\text { of the original }\end{array}$ & $\begin{array}{l}\text { Substitution with } \\
\text { a superordinate } \\
\text { item } \\
\text { Substitution with } \\
\text { an international } \\
\text { term }\end{array}$ & $\begin{array}{l}\text { Superordinate } \\
\text { term or } \\
\text { paraphrase }\end{array}$ \\
\hline SUBSTITUTION & $\begin{array}{l}\text { Replacement } \\
\text { with deictics }\end{array}$ & $\begin{array}{l}\text { Substitution with } \\
\text { a different SC } \\
\text { item } \\
\text { *Substitution } \\
\text { with a target- } \\
\text { culture item }\end{array}$ & \\
\hline EXPLICATION & $\begin{array}{l}\text { Paraphrased } \\
\text { explanation }\end{array}$ & & $\begin{array}{l}\text { Specification: } \\
\text { a) addition } \\
\text { b) completion }\end{array}$ \\
\hline
\end{tabular}

Table 4 Similarities and differences of the existing typologies

If the above strategies are applied to our illustrative corpus of CSIs, the outcome is Table 5. It provides the summary of how the 
translation strategies given in the typologies of Newmark (1988), Tomaszkiewicz (1993), Valdeon (2008), and Pedersen (2011) can be applied to our examples. In the filled boxes are the tags used by respective authors. If the tag is absent (a short dotted line is used instead), it means that the author does not recognize this category in his typology. If the tag is present in the box, it means it corresponds with the translator's decision in the context provided by the communicative situation. In our illustrative corpus, one example is very specific, which is why an asterisk is used. Even though the category is present in the author's typology, it does not correspond with the decision that the translator took. For example, Tomaskiewicz uses the term naturalization instead of generalization; however, in this very example, naturalization is not the result of the translation process. It follows that one strategy will not necessarily cover all seemingly similar communicative situations; moreover, a CSI may not automatically be matched with one strategy in all communicative situations in which it occurs.

\begin{tabular}{|c|c|c|c|c|}
\hline & Translation strategi & & & \\
\hline & Newmark (1988) & $\begin{array}{l}\text { Tomaszkiewicz } \\
\text { (1993) }\end{array}$ & $\begin{array}{l}\text { Valdeon } \\
\text { (2008) }\end{array}$ & $\begin{array}{l}\text { Pedersen } \\
\text { (2011) }\end{array}$ \\
\hline Nick at Night & generalization & * & $*$ & * \\
\hline Kilt & $\begin{array}{l}\text { omission }+ \\
\text { explication (with a } \\
\text { shift) }\end{array}$ & $\begin{array}{l}\text { omission }+ \\
\text { paraphrased } \\
\text { explanation }\end{array}$ & --- & $\begin{array}{l}\text { omission + } \\
\text { specification } \\
\text { (addition) }\end{array}$ \\
\hline First Melville & borrowing & borrowing & preservation & Retention \\
\hline $\begin{array}{l}\text { Private school } \\
\text { girl }\end{array}$ & generalization & $\begin{array}{l}\text { naturalization } \\
\text { of the original }\end{array}$ & $\begin{array}{l}\text { substitution } \\
\text { with a super- } \\
\text { ordinate term }\end{array}$ & $\begin{array}{l}\text { Superordi- } \\
\text { nate term }\end{array}$ \\
\hline Ambulance & $\begin{array}{l}\text { literal translation, } \\
\text { *improper }^{\text {impro }}\end{array}$ & $\begin{array}{l}\text { literal } \\
\text { translation }\end{array}$ & --- & $\begin{array}{l}\text { Direct transl. } \\
\text { shifted }\end{array}$ \\
\hline
\end{tabular}

\subsection{Pym (2016)}

The observation on the applicability of translation strategy to a CSI and a communicative situation directs our attention to an important fact. Pace Newmark (1988), Tomaszkiewicz (1993), Valdeon (2008), and Pedersen (2011), CSIs occur in so many communicative situations that it may as well be impossible to find a matching translation strategy from those discussed. The latest contribution to the typologies of translation strategies is the taxonomy of translation solutions proposed by Pym (2016). He intentionally moves from the 
concept of strategy to the concept of solution. Pym (ibid) differentiates strategies from solutions based on some characteristics; he (ibid, p. 175 , his italics and single quotation marks) assumes that solutions, rather than strategies, are

... behavioral (not neural), linguistic (used when manipulating texts), goal-oriented (they are solutions), problem-based (they start from trying to solve a local textual problem, not on the level of the whole text), potentially conscious (they are not routine, background activities), intersubjective (they can spread through a community of translators, which is why they are 'memes').

Pym adopts Chesterman's (1997 In Pym 2016) bottom-up approach, starting from the most general and basic translation solution, i.e. changing something.

In his typology of translation solutions, Pym (2016) draws on what the translator might be considering: copying the source language item, changing its form (expression), or changing its content (tinted areas in Table 6). These three mapping operations are further reflected in seven categories, see Table 6. Each can be subdivided into further subcategories according to the purpose of the translation, language pair conditions, and the like. They do not represent an exact taxonomy; rather an open system consistent with the translator's needs.

Translation solutions

$\begin{array}{lll}\text { Copying } & \text { Expression change } & \text { Content change } \\ \text { Copying words } & \text { Perspective change } & \text { Text tailoring } \\ \text { Copying structure } & \text { Density change } & \\ & \text { Compensation } & \\ & \text { Cultural correspondence } & \end{array}$

Table 6 Pym's typology of translation solutions

He (ibid.) views the process of translating to be operating on two modes: a cruise mode and a bump mode. The former refers to the "normal use of language skills, reference resources, parallel texts, intuition [...] so no special solutions are needed" (Pym 2016, 220). The bump mode, in his view, is a situation when a translator needs some help, and this is when the proposed solutions should be contemplated. In his (ibid) view, whenever a translator can rely on his/her language skills, available language and encyclopedic material, and intuition, a typology appears to be irrelevant. It may prove to be of assistance solely in critical situations. He presents a typology accounting for what a translator actually needs during translating a text. 
The above claims make us believe that Pym's typology is more user-friendly, i.e. translator-friendly in that he offers terms that are at once narrow and broad; narrow in the sense of being direct about the route to be taken, and broad in the sense of allowing for options within certain limits but not being too rigorous. We consider translating a CSI to be a typical bump situation, when the translating process does not go smoothly, and a crutch is necessary. He (ibid) suggests that three questions be asked: Should I keep the form? Do I need to change the form? Do I need to change the content? Instead of advocating a theoretical construct (not necessarily overtly expressing the mere operation to be adopted), he explains what is going on in a translator's mind. In in addition to the above discussed translation strategies, Table 7 presents our understanding of how Pym's translation solutions can be applied to the examples from our illustrative corpus. The table points out the effortless nature of Pym's typology (2016). Though not specifically intended for CSIs, we believe it has the potential to compete with the existing approaches and has high chances of being a practical guide in finding solutions to translation problems, or to what Pym (2016) calls bump situations.

\begin{tabular}{|c|c|c|c|c|c|}
\hline & Translation stra & egies & & & Tr. solutions \\
\hline & $\begin{array}{l}\text { Newmark } \\
(1988)\end{array}$ & $\begin{array}{l}\text { Tomaszkiewic } \\
\text { z (1993) }\end{array}$ & $\begin{array}{l}\text { Valdeon } \\
\text { (2008) }\end{array}$ & $\begin{array}{l}\text { Pedersen } \\
\text { (2011) }\end{array}$ & $\begin{array}{l}\text { Pym } \\
\text { (2016) }\end{array}$ \\
\hline $\begin{array}{l}\text { Nick at } \\
\text { Night }\end{array}$ & generalization & $*$ & $*$ & $*$ & $\begin{array}{l}\text { Content } \\
\text { change }\end{array}$ \\
\hline Kilt & $\begin{array}{l}\text { omission } \\
\text { explication } \\
\text { (with a shift) }\end{array}$ & $\begin{array}{l}\text { omission } \\
\text { paraphrased } \\
\text { explanation }\end{array}$ & --- & $\begin{array}{l}\text { omission } \\
+ \\
\text { specificat } \\
\text { ion } \\
\text { (addition } \\
\text { ) }\end{array}$ & $\begin{array}{l}\text { Expression } \\
\text { change }\end{array}$ \\
\hline $\begin{array}{l}\text { First } \\
\text { Melville }\end{array}$ & borrowing & borrowing & $\begin{array}{l}\text { preservat } \\
\text { ion of a } \\
\text { CSI }\end{array}$ & retention & Copying \\
\hline $\begin{array}{l}\text { Private } \\
\text { school girl }\end{array}$ & generalization & $\begin{array}{l}\text { naturalization } \\
\text { of the original }\end{array}$ & $\begin{array}{l}\text { substituti } \\
\text { on with a } \\
\text { super- } \\
\text { ordinate } \\
\text { term }\end{array}$ & $\begin{array}{l}\text { Superord } \\
\text { i-nate } \\
\text { term }\end{array}$ & $\begin{array}{l}\text { Content } \\
\text { change }\end{array}$ \\
\hline Ambulance & $\begin{array}{l}\text { literal } \\
\text { translation, } \\
\text { *improper }\end{array}$ & $\begin{array}{l}\text { literal } \\
\text { translation }\end{array}$ & --- & $\begin{array}{l}\text { Direct } \\
\text { transl. } \\
\text { shifted }\end{array}$ & Copying \\
\hline
\end{tabular}

Table 7 Translation strategies vs translation solutions applied to CSIs 


\subsection{Pym's Typology (2016) versus Typologies by Newmark (1988), Tomaskiewicz (1993), Valdeon (2008), and Pedersen (2011)}

The comparison presented above takes us to the evaluation of the correspondence between terminology contained in Pym's typology and in the typologies by Newmark (1988), Tomaskiewicz (1993), Valdeon (2008), and Pedersen (2011). Based on the establishment of conceptualization, Pym's solutions encompass the translation strategies as presented in Table 8.

Translation solutions Pym (2016)

\begin{tabular}{ll} 
Copying & $\begin{array}{l}\text { Copying words } \\
\text { Copying } \\
\text { structure }\end{array}$ \\
& $\begin{array}{l}\text { Perspective } \\
\text { change }\end{array}$ \\
& \\
\hline $\begin{array}{l}\text { Expression } \\
\text { change }\end{array}$ & Density change
\end{tabular}

Compensation

Cultural correspondence

Content Text tailoring
change

Pedersen

Valdeon
Translation strategies

Newmark (1988), Tomaskiewicz (1993), Valdeon (2008), and Pedersen (2011)

Newmark Transference, Borrowing, Literal translation

\begin{tabular}{ll}
\hline Tomaskiewicz & Literal translation, Borrowing \\
\hline Valdeon & Preservation of international items \\
& Preservation of culture specific items \\
\hline Pedersen & Direct translation, Retention
\end{tabular}

Newmark Transposition, Modulation

Tomaskiewicz Adaptation

Pedersen Slightly adapted (TL-adjusted) form

Newmark Descriptive equivalent, Functional equivalent, Paraphrase, Recasting

Tomaskiewicz Generalization/neutralization of the original, Explication or a paraphrased explanation of the cultural term

Pedersen Generalization (superordinate term or paraphrase), Specification (addition and completion)

Newmark Compensation

Newmark Cultural equivalent

Tomaskiewicz Equivalence

Newmark Reduction, Expansion, Notes, Additions, Glosses

Tomaskiewicz Omission/Replacement of the cultural term with deictics

Substitution with a superordinate term, S. with an international item, S. with a different source culture item, S. with a target-culture item

Substitution (cultural or




\section{situational)}

Omission

Table 8 Translation solutions vs. translation strategies

The table offers our understanding of content correspondence between the terms concerned. In addition, it makes clear, for example, that Pederson does not consider expression change (i.e. change of the form) in his typology. To substantiate the content correspondence between the terminologies concerned, we used the socio-cognitive conceptualization process the essence of which lies in accounting for and aligning three sub-processes: frame establishment, encoding, and contextualization (Bilá, Kačmárová, Vaňková, 2017). Establishing a frame means defining a broader context into which the term belongs. Encoding implies the explanation of what the term stands for so that pre-understanding can be supported. The contextualization of the term is done through exemplification, whether by means of vocabulary sample, discourse sample, or a specific procedure embodying the solution of a specific communicative situation. The first two, thus, represent the cognitive side; the third one represents the social side of conceptualization. The below conceptualization is based on Pym (2016, pp. $224-231)$.

1. COPYING

Frame TRANSLATION SOLUTIONS

Encoding it is based on imitation the original sound, word, etc., from the smallest to the hierarchically higher structures

Contextualization, see

copying words/structure

Copying words/structure

Frame COPYING

Encoding it is based on the usage of an expression that imitates the sounds, word structure, or orthography/script, prosodic features, fixed phrases, text structure

Contextualization

literal translation, calque, international vocabulary, borrowing

2. EXPRESSION CHANGE

Frame TRANSLATION SOLUTIONS

Encoding it is based on changing the form in the sense of:

1. changing a perspective, 
2. changing the density of the expression,

3. compensation of the expression,

4. cultural correspondence

Contextualization, see

1. Perspective change

2. Density change

3. Compensation

4. Cultural correspondence

Perspective change

Frame EXPRESSION CHANGE (a type of translation solutions) Encoding it is based on seeing a referent or object from a different angle, these processes make part of it:

a) changing sentence focus;

b) changing semantic focus;

c) changing voice;

Contextualization

a) changing active sentences to passive, positive statements to negative ones, verbal structures to nominal ones, changing directionality, etc.

b) changing culture values

c) in the sense of tone, or changes in register, e.g. pronoun structure (tous/vous), imperative vs. we in recipes, I vs we to indicate authorship in papers, etc.

\section{Density change}

Frame EXPRESSION CHANGE (a type of translation solutions)

Encoding it is based on changing the "proximity" to the referent:

a) generalization,

b) specification,

c) explicitation/implicitation,

d) resegmentation, i.e. using different amount of text to cover the same information.

Contextualization
a) using a hyperonym
b) using a hyponym
c) expressing the same idea by different grammatical means
d) cutting a complex sentence into two shorter ones

\section{Compensation}

Frame EXPRESSION CHANGE (a type of translation solutions) 
Encoding it is based on opting for a new linguistic level:

a) either a new place in text added

b) or a new level of expression added, Contextualization

a) footnotes, endnotes: explicitation + compensation, addition + compensation

b) suggestion to tous address ("Môžeme si tykat') vs. "My friends call me Bill."

\section{Cultural correspondence}

Frame EXPRESSION CHANGE (a type of translation solutions) Encoding it is based on looking for

a) corresponding idioms

b) corresponding culture-specific items Contextualization

a) "to carry coal to Newcastle" vs "nosit' drevo do lesa" (the latter in English: carry wood to the woods)

b) Sookie: I've got to make strawberry shortcake for 200 people. I think I'm gonna need strawberries.

Sookie: Ale ako mám upiect' jahodový koláč pre 200 l'udí bez jahôd. [the literal translation into English would be strawberry pie]

\section{CONTENT CHANGE}

Frame TRANSLATION SOLUTIONS

Encoding a translation solution based on the content of the expression so that the message is communicated in line with the target culture and its audience/readership

Contextualization, see Tailoring

\section{Tailoring}

Frame CONTENT CHANGE (a type of translation solutions)

Encoding it is based on accommodating the content to the social, geographical, cultural, etc. circumstances

Contextualization

addition, omission, censorship, updating, correction, etc.

The description of the notions was based on three pieces of information: the broader context (the umbrella term it falls within), the definition of the term, and the exemplification of the term. Such a procedure has made available detailed information about the term and made it possible to compare the scope and content of individual terms. 


\section{Conclusion}

CSIs are distinctive material for translation due to their heterogeneous nature. This is also a reason for their being a problematic area in the translation process, or what Pym calls "bump situations" (2016, p. 220). The history of translation studies witnesses many attempts in setting typologies and identifying categories that would capture their unpredictable character. The diversity and range of existing taxonomies that CSIs fall within anticipate the complex nature of their translation. Each CSI is so distinctive that it may as well deserve individualized approach. In a translator's endeavor to treat the CSI as appropriately as possible, s/he needs to make proper choice from an array of alternatives. We conducted a study on existing terminologies of translation strategies and their conceptualizations in order to streamline theoretical support that a translator can resource to when necessary.

Pym's (2016) typology of translation solutions has proved itself to account for a language unit as a bilateral language sign with its signified and signifier, i.e. content and form. His terminology seems to work universally, as in our case, it suffices to cater for CSIs and the English-Slovak language pair. In his attempt to simplify the procedure of translation he asks the basic questions related to the two facets of a linguistic sign - form and content. This is reflected in his terminology he offers three general areas copying (form), expression change (i.e. changing signifier), content change (i.e. changing signified).

Our basic premise was that Pym's typology would be more user-friendly (i.e. translator-friendly). The analysis has shown that Pym's concepts can be applied to specific lexis (like CSI), to a specific mode (like film dialogue), and to the Slovak language. In general, they are more transparent and more consistent in the perspective used as they do not combine translator's and reader's perspectives. Hence, we assume they are more easily applicable in the translating process and more readily applicable in teaching translation strategies; or rather solutions, as Pym calls them, since he claims that they show that our primary concern is a solution, not the strategy the route a translator is taking). 


\section{References:}

Bilá, Magdaléna, Kačmárová, Alena, Vaňková, Ingrida. "What is behind the compiling of a dictionary for a bilingual user?" Evolving nature of the English language: studies in theoretical and applied linguistics, Franfurkt am Main: Peter Lang, 2017, pp. 201-209.

Nida, Eugene. Language structure and Translation: Essays by Eugene A. Nida. Stanford: Stanford University Press, 1975.

Newmark, Peter. A Textbook of Translation, London: Prentice Hall, 1988.

Nord, Christianne. Translating as a purposeful Activity. Functionalist Approaches Explained. Manchester: St. Jerome Publishing, 1997.

Pedersen, I. Subtitling norms for television. Amsterdam: John Benjamins Publishing Company, 2011.

Pym, Anthony. Translation Solutions for Many Languages. Histories of a Flawed Dream. London/New York: Bloomsbury, 2016.

Sipko, Jozef. "Jazyková prezentácia hodnôt," Jazyk a kultúra, vol. 1, No. 3, Prešov: Prešovská univerzita, 2010.

Tomaszkiewicz, Teresa. (1993). Ider. Les opérations linguistiques qui sous-tendent le processus de sous-titrage des films. Poznan: University Adam Mickiewicz In Horbačauskienè, Jolita et al. "Issues of culture specific item translation in subtitling," Procedia - Social and Behavioral Sciences 231 (2016): 223-228

Valdeon, Roberto A. 2008. "Alienation techniques in screen translation: The role of culture specifics in the reconstruction of targetculture discourse," Language in Contrast 8 (2): 208 -234.

Vlachov, Sergej I., Florin, S. Neperevodimoe $v$ perevode. Moskva: Mezhdunar otnosheniia. 1980. $342 \mathrm{~s}$.

Funding Acknowledgment: This paper is part of the research grant project KEGA 007PU-4/2015 Virtual interactive encyclopedic English-Slovak and Slovak-English dictionary of general linguistics.

\section{EXISTUJE UNIVERZÁLNA TYPOLÓGIA PREKLADATELSKÝCH RIEŠENÍ KULTÚRNE ŠPECIFICKÝCH VÝRAZOV?}

Перевод единиц специфичных для культуры на другой язык, всегда был проблемой для переводчиков по понятным причинам: они контекстно-зависимые текстовые элементы, 
несущие коннотативный смысл в исходной культуре. По той же причине доступны несколько типологий, таких как Newmark (1988), Tomaszkiewicz (1993), Valdeon (2008) или Pedersen (2011). Типология Newmarka была в целом принята экспертами в области перевода и педагогики перевода. Восемь стратегий Tomaszkiewicza (1993) основаны на изучении субтитров в фильмах. Таксономия Valdeon (2008), основанная на аудиовизуальном режиме, включает стратегии связанные с сохранением и замещением. Таксономия Pedersena (2011) включает категории ориентированные на родной язык и язык перевода. Их можно сопоставить с таксономией Пима (Руm-а) (2016), которую он называет типологией переводческих решений для многих языков. Он (2016) предполагает, что они поведенческие, проблемные, потенциально сознательные, интерсубъективные и исходя из самого общего и основного решения для перевода: что-то изменить. С появлением чего-то нового может возникнуть несколько вопросов: зачем нам нужна еще одна классификация? Как этот подход отличается? Наша основная предпосылка заключается в том, что типология Пима (2016) более удобна для пользователя (т. е. для переводчиков). Настоящая работа направлена на сравнение и сопоставление существующих типологий и тем самым упрощение текущей тенденции в теории перевода.

Ключевые слова: единица специфична для культуры, стратегии перевода, решения для перевода, диалог фильма, Рут (2016) (Пим), Pedersen (2011), Valdeon (2008), Tomaszkiewicz (1993), Newmark (1988). 